\title{
Determinants of Foreign Banking Activity in Pakistan
}

\author{
Nighat Bilgrami-Jaffery • Amber Fatima
}

Published online: 20 December 2012

(C) CEEUN 2012

\begin{abstract}
The paper attempts to investigate the factors determine the level of foreign banking activity in Pakistan in context of central banks policy framework for the period 1973-2008. Greater emphasis is given to examine the factors, responsible for the influence of foreign banking activity in Pakistan in short run and long run time frame work. The outcomes clearly indicate that market size, trade and corporate financing are the main activities of foreign banks and foreign banks mainly concentrate in trade financing with highly concentrating on export financing activities of their home country. The entry and existence of foreign banks can make domestic banks competitive and efficient. Pakistan may acquire benefits with the growth of foreign banks by improving their efficiency, competitiveness and trade financing activities.
\end{abstract}

Keywords Foreign banks $\cdot$ Trade finance $\cdot$ Export financing $\cdot$ Efficiency $\cdot$ Pakistan

JEL Classification $\quad 016 \cdot \mathrm{G} 21 \cdot \mathrm{F} 13 \cdot 043$

\section{Introduction}

During the last decade foreign banking activity has considerably increased in several emerging economies. Some countries such as Argentina, Hungry, Chile, Czech Republic, and Poland have experienced tremendous foreign bank participation where as in several other developing economies of Asia, Africa, Middle East this trend has been slower. Over $50 \%$ of total banking assets are now in

N. Bilgrami-Jaffery $(\bowtie) \cdot$ A. Fatima

Applied Economics Research Centre, University of Karachi, Karachi, Pakistan

e-mail: nighatbj@yahoo.com

A. Fatima

e-mail: amber_aerc@hotmail.com 
foreign-controlled banks in emerging economies (Clarke et al. 2001). Pakistan being no exception also experienced increased foreign bank participation in recent years. According to Horen (2006), foreign bank entry refers to a process through which foreign banks set up operations in host country mainly by either opening up a branch or a subsidiary.

In the recent past due to the process of globalization and financial liberalization, banking activity has increased at a faster pace in the developing countries and the foreign banks from developed economies, i.e. belonging to rich and higher income countries started their operation in developing economies. The high interest margin (spread) in developing countries attracts the foreign banks to start their operations in developing countries. ${ }^{1}$ Not only this economic agent has also belief that foreign banks react more pro-cyclically to change the host country macroeconomic environment, then the home country bank generally reallocates capital over different geographical regions on the basis of expected risks and returns.

In Pakistan an average banks are charging approximately $18 \%$ on advances/ loans to borrowers and paying much less approximately $11 \%$ on customers' deposits. This gives an earning spread of $7 \%$ which is considered very high as compared to developed countries spread is around $2 \%$ and in few cases even lesser. Reforms carried out in the investment environment, improving macroeconomic performance along with the high foreign trade and growth potentials of Pakistan are the factors pulling the foreign banks to invest in Pakistan. These banks start their operation in the host country with the aim to increase the efficiency, competitiveness and improve the financial system. High efficiency and an effective banking regulation seem to have a positive relationship. In many developing countries foreign banks also introduced the risk management practices and trade supervision from home country regulator for strengthening of the banking system. As it is quoted by the World Bank (2001), a good financial system is sure to be an essential ingredient for sustainable economic growth and poverty reduction (Claessens and Lee 2002).

The entry of foreign bank and their active participation also helps the better application of modern banking skills and technologies in the conservative and weak banking system of third world countries. Moreover it also initiates the development of the bank supervision and legal framework and motivates the domestic banks to improve their efficiency and quality of financial services in order to remain competitive and retain their market share (Lensink and Hermes 2004).

The aim of this study is to investigate the determinants and factors which are strongly impact on the presence of foreign banking activity in Pakistan in short run period of time and ling run. The study is categorized as follows. Second section gives the review of literature discussing the conclusion of various studies and than the history of Foreign Banking and the impact of central bank policies on the same discussed in third section. Data, model and methodology is presented in fourth section followed by the empirical results in fifth section. The final section gives the summary and conclusion.

\footnotetext{
${ }^{1}$ Spread is the differential between the rate charged by banks on advances and paid to customers on deposits.
} 


\section{Review of Literature}

Many studies done on the banking sector focused on the question why banks are motivated to begin operations outside their home country, i.e. in the foreign land? These studies have tried to explain the factors behind their motivation.

Ahmad and Rosly (1995) studied the determinants of foreign bank activity in Malaysian economy. They used the time series data for the period 1966-1993 and found that foreign banks with trade financing as the main activity did not have an impact on the growth of Malaysian economy and growth of domestic banks occurred at the expense of foreign banks. However no evidence is seen for the influence of foreign investment on asset and representative offices of foreign banks. They required an in depth study of sources of finance of subsidiaries of foreign companies in Malaysia.

Similarly, Fisher and Molyneux (1996) examined the determinants of foreign bank activity in London, according to the country of origin of investing banks between 1980 and 1989. Results indicated that the size of the banking sector in the foreign country is positively correlated with that country's bank presence in London. Foreign bank presence is also likely to be greater among main trading partners and also appeared that foreign direct investment from European and nonUS or Japanese sources has a positive impact on foreign bank presence from those countries.

Sonin and Yudkevich (2000) studied the possible effect of foreign bank entry on the domestic banks of transitional economy. Their theoretical model considered the conditions which the entry of foreign banks creates, e.g. additional incentives for domestic banks. They argued that efficient implementation of bankruptcy legislation is important pre condition for the foreign banks entry. Their paper analyzed the mixed outcomes of foreign banks entry in Hungary and Poland and derived the policy implication for Russia.

Sathye (2002) examined that the foreign banks presence has helped to reduce concentration in the Indian banking market and thus increased competition among banks. $^{2}$ Their results showed that entry of foreign banks did not have significant impact on reducing the level of concentration in the Indian banking market because many restrictions still in place on foreign bank activities in India. Hence this efforts being made to establish level playing field among all banks need to be continued so as to make Indian banking market competitive.

Paula (2003) analyzed the determinants of the entry of foreign banks into banking retail market and the strategies of the major European banks in Brazil. He showed that the recent wave of banking internationalization is characterized not only for financial institutions pursuing their existing relationships, but also by a greater integration into the local market. ${ }^{3}$ The author found that the features of the

\footnotetext{
${ }^{2}$ Concentration has been measured using the Herfindahl-Hirschman index of concentration.

3 The waves of European banks entering Latin America and Brazil is determined by a set of different factors that includes the process of bank restructuring in Europe; the dynamics of the internationalization of the Spanish banks and the process of market deregulation in the region.
} 
major European banks are that they are big universal banks that choose to expand abroad as a strategy to expand their activities.

Wezel (2004) investigate the macroeconomic and financial sector risk factors in the location decisions of multinational German banks for the period 1994-2001. ${ }^{4}$ The outcomes indicated that FDI by non-banks exerted a strong pull effect on FDI flows of banking sector as highly developed financial markets and a low country risk. He found that there is no particularly and meaningful effects for the per capita GDP or trade linkages. The financial crisis also turned out the highly negatively correlated with the FDI flows. Comparing to pre- and post-Asian-crisis time periods, it was found that both variables of country riskiness gain significance with the measure of financial vulnerability.

Haselmann (2006) examines the strategies of foreign banks in transitional economies. He outlined different strategies of foreign banks entry decision by estimating a loan supply function. In their opinion foreign banks and domestic banks compete in same market segments. He concluded that the behavior of foreign banks was independent of macroeconomic condition prevailing in foreign banks origin of country.

Lehner and Schnitzer (2006) demonstrate that how the foreign banks increased the competition among foreign banks in local market and how these banks affect on host countries. They argued that with the increasing foreign banks activity, it affects positively on welfare of competitive market where as the spill over effect weaken the economy.

Detragiache et al. (2006) reviewed how foreign bank penetration affects financial sector development in poor countries. A theoretical model presented show that when domestic banks are better than foreign banks at monitoring soft information customers, foreign bank entry may hurt these customers and worsen welfare. The model also predicts that credit to the private sector should be less in countries with more foreign bank penetration, and that foreign banks should have a less risky loan portfolio.

Palit and Nawani (2007) attempts to explain the country-wise variations in the pattern of FDI flows to developing Asian economies by empirically identifying location specific features influencing such flows. They argued that some countries in the region, which have developed long term sources of comparative advantages in the form of superior technological capabilities and supporting infrastructure, have consistently attracted greater volumes of export-oriented FDI. Results indicate that with production processes becoming increasingly complex and technology-intensive, developing countries like India, must devote greater attention to the development of R\&D and frontier technology failing which, they might lose out in the race for FDI.

Akmal and Saleem (2008) used a sample of 30 banks (4 public, 18 local private and 8 foreign banks) for two stages Data Envelopment Analysis (DEA) to provide evidence on the impact of macroeconomic and bank specific factors on banks' efficiency. Their outcomes indicated that banking efficiency has improved since

\footnotetext{
${ }^{4}$ The author selected the emerging markets of Central and Eastern Europe, Latin America and Asian countries.
} 
2000 and foreign banks are more efficient than local private and state owned banks in case of Pakistan due to technological and total factor productivity growths during 1995-2005.

Haddad and Hakim (2009) analyzed the role of domestic and foreign banks in the economy of Saudi Arabia. The authors found that there is a doubt that partly owned foreign banks are more risk exposed than their purely domestic counterparts and do not found evidence that foreign shareholders of Saudi banks suffered losses and liquidity problems in their home countries and cut credit in Saudi Arabia nor acted in a manner inconsistent with their domestic counterparts. Their evidences was not supported the double standard in banking regulation.

\section{History of the Financial Sector}

At the time of independence in 1947 the areas which became Pakistan had no representation in terms of banking and financial system. In fact there were no financial and capital markets at the time of independence. With only few bank branches during that time, the financial sector has expanded exponentially. Now there are bank branches even in the rural areas of the country.

The State Bank of Pakistan (SBP) began its operation on 1 July 1948 and started working and establishing a robust banking system for newly born Pakistan. During the first 2 years SBP successfully opened 51 new branches in both East and West Pakistan. These comprised of, 28 Pakistani banks, 12 Indian, 4 exchange (foreign banks) and 7 branches of newly established National Bank of Pakistan-by the end of the second year, i.e. 1949, 35 scheduled banks were formed in Pakistan, i.e. 4 Pakistani, 23 Indian and 8 exchange banks, having 192 branches in both East and West Pakistan. Exchange banks are confined to the port towns as their main function was import/export (i.e. trade financing) and allowed to open branches in provincial capitals to cater to the needs of multinationals firms that required banking services and had trade with foreign countries.

In any developing economy, the commercial banks are recognized for their vital role in the economy to enable to continue to meet the ever growing demand to credit. The role of SBP and commercial banks widened with the increase in the number of branches-role of the commercial banks is to mobilize domestic savings and deploy them in promoting commercial and industrial activities. Mostly credit was used to finance foreign trade and commerce. It also caters to the demand for credit to domestic industries as well. As the banking sector expanded and number of branches continued to grow in developed/big cities, SBP decided to setup a system of opening of new branches under which a certain quota of branches had to be opened in under developed/under banked areas designated by the SBP. With this initial setup SBP continued reshaping/reforming the rules and regulations for the banking sector. Today we have a comprehensive set of regulations is in place and banking services are available also in the remote regions of Pakistan.

State Bank of Pakistan, being the Central bank of Pakistan, is the sole supervisor and the regulatory authority of commercial banks, Islamic Banks, Development Financial Institutions, Micro finance banks and Exchange Companies in Pakistan. 
The financial sector in Pakistan was opened to private sector (both for local and foreign investors) in 1989 as a part of federal government policy of deregulation and privatization of financial sector. The following categories were allowed to conduct banking business in branch mode as well as partially wholly owned locally incorporated subsidiary:

(a) Banks from countries belonging to regional groups and associations of which Pakistan is a member.

(b) Foreign banks having a global tier-1 paid up capital of US\$5 billion or more. Moreover a foreign corporate entity/body desirous of conducting banking business in Pakistan must establish a locally incorporated company with a maximum of $49 \%$ share holding by the foreign strategic investor/entity/ financial institution. In addition the opening of up to ten branches immediately after the commencement of business till December 31 of the calendar year is required.

Before privatization, Pakistan's financial sector comprised of a central bank, SBP, Commercial banks, Non-Bank Financial Institutions (NBFIs) and insurance companies. The commercial banking sector consists of 5 Nationalized Commercial Banks (NCBs), 2 state owned provincial banks, 2 privatized commercial banks, 14 private banks and 10 foreign banks (see Table 6 in "Appendix").

Pakistan was initiated its financial sector liberalization under the broader macroeconomic structural adjustment programs in the decade of 1990s. Pakistan is included in that countries that has successfully transferred the possession and larger shares of their financial sector from public to private ownership along with other financial, trade and industrial policy measures in a short period of time. When the performance and efficiency of state owned nationalized and commercial banks are reviewed, there was a significant difference is observed. During the period 1996-1999 foreign banks showed highest growth rates in terms of deposits with an annual growth of $31.4 \%$, as compared to $12.7 \%$ of NCBs and $18.2 \%$ for the privatized banks.

A major decision regarding the banking sector reforms came in the year 1991 when the government allowed establishment new private commercial banks. In 1991-1992 the governments issued licenses to the new banks in the private sector and continue to do so since then. Before, the banking system consisted of the five main nationalized banks and a little over two dozen foreign banks. Since the late 1990s the banking sector came across many changes in Pakistan. The number of foreign banks has fallen considerably from 22 in 1996 to 16 in 2003 and only to 9 currently. Few of the foreign banks have left Pakistan because the country's economy was not doing well, particularly after the nuclear test during 1998 and the freezing of the foreign currency accounts by Pakistan government. It is evident from the history of the banking sector development that industrialization and the economic development are closely linked with the development of the banking sector.

Financial sector plays a vital role in the economic growth of any country. Pakistan is the seventh largest country in South Asia and is characterized by many and varied financial institutions and instruments. Pakistan banking sector was 
developed even during the British rule that is, prior to her political independence from British in 1948. Now we find significant presence of both Foreign and domestic banks and developing stock market.

At the end of June 2008 there are 7 foreign banks functioning in Pakistan as compared to 17 in 1975 and 26 in 1990. The number of foreign banks has declined due to the regulatory factor and uncertainty in economic growth of Pakistan. In 2008 growth rate of deposits of foreign banks was $3.50 \%$ as compared to growth rate of $28.40 \%$ in 1980 (see Table 7 in "Appendix").

The reasons for rising of foreign banking activities in Pakistan are the Population (market size of economy), no limitation to foreign ownership of banks, Easier entrance to the Pakistan market, the investment friendly environment of Pakistan and highly liberalized investment policy, high rate of return (interest rate), Foreign trade and growth potentials, Equal treatment of Pakistanis and foreign bank, Consumer credits and mortgage. The foreign banks have an edge over Pakistani banks as they have world wide network and vast banking experience. Foreign banks are mainly concentrated in the field of foreign trade financing with great emphasis on export financing.

Foreign banks are therefore, playing a dynamic role in promotion of foreign trade of Pakistan and are fully authorized to conduct all normal banking functions including the acceptance of deposits from public. The branches of foreign banks are located in almost all major cities. All the Euro dollars loans syndicates for the government of Pakistan have been managed by foreign banks. The foreign banks have also played an important role in the field of air craft financing, leasing and hire purchase.

\section{Model, Methodology and Data Sources}

On the basis of the theoretical review and empirical studies, we suggest the following model by assuming log linear association among variables for empirical investigation in the context of Pakistan. A log linear association is assumed since there is no strong functional form. The study examines the determinants that could significantly effects the total deposits of the foreign banking activity in Pakistan and to investigate the dynamic relationships among the variables, i.e. the deposits of foreign banks, real growth rate (GDP), trade to GDP ratio, FDI to GDP ratio, population growth, interest rate and regulatory factor in short run and long run.

$$
L Y_{t}=\beta_{0}+\beta_{1} L G_{t}+\beta_{2} L M_{t}+\beta_{3} L F D I_{t}+\beta_{4} L P O P_{t}+\beta_{5} L I N T_{t}+\beta_{6} L R E G_{t}+v_{t}
$$

where $\mathrm{Y}$ is the total deposits of foreign banks in Pakistan, which represents the foreign banking activity in Pakistan, lower deposits indicate low activity and higher deposits indicate higher activity. G is GDP, reflects the general performance of the economy and provides an indication of the size of the local market for the Foreign banks, higher GDP always benefit the banking activity in saving-oriented society by increasing the purchasing power of consumers. Whereas in consumption oriented society the higher GDP The rising of current income always perceived the higher consumption of individuals rather than saving in the consumption oriented society. 
Trade (M) is total exports and imports as the \% of GDP, used to demonstrate the effect of trade financing and corporate financing activities on the foreign banks in context of Pakistan. Greater foreign trade should increases growth of foreign banks to service the business because that without the physical presence of banks the trade operations of domestic exporters abroad face difficulties and sometimes to become not viable. The other advantage of foreign banking is the information and personal contacts between banks and a trading firm's in a foreign country at a low cost, higher efficiency and advanced technology with diversification and integration to domestic markets. Their expected sign of this coefficient is positive.

FDI is the foreign direct investment as \% of GDP; similarly greater FDI increases the potential business for foreign banks and should have a positive sign. POP is Population growth rate (market size) and used as a measure of market size. Market size is important for economies of scale, because a larger market offers the potential for exploiting economies of scale and declining the marginal costs of production. Thus, Countries that have large domestic markets tend to be more opened, because foreign banks need external markets other than host country to expand their activities. Thus the larger a country is the higher will be the foreign banks in that country. Its expected sign is also positive. INT is the real interest rate and is used to check the impact of exchange rate and rate of return in economy on the foreign banks. Higher returns always attract the banks and increase the deposits of foreign banks. So, expected sign should be positive for demonstrating the profitability of foreign banks.

REG. is a regulatory factor which tries to capture the impact of discriminatory policies against foreign banks. Increasing the international trade, improving technology in order to modernize the domestic banking sector, increasing the product and service variety is the prospect of the host country for given license to foreign banks. Their coefficient should be expected positive. A dummy variable is used for expectation regulatory effect, whose value is 0 and 1 , which has been done to detain the effect of complete prohibition on giving license to foreign banks and allowing them to open their branches in host banks.

\section{Methodology}

As we know that all macroeconomic variables shows some trend, that why before testing of ordinary least squares (OLS), we test the properties of individual time series. Formally, we test the unit root in order to consider the stationarity properties of the data; augmented Dickey-Fuller (ADF) test-statistics (Dickey and Fuller 1979) and Phillips and Perron (PP) test (1988) used for all variables. ${ }^{5}$ In unit root tests, the ADF test consists of estimating the following regression equation;

$$
\Delta Y_{t}=\beta_{1}+\beta_{2} t+\delta Y_{t-1}+\lambda_{i} \sum_{i=1}^{m} \Delta Y_{t-1}+\varepsilon_{t}
$$

where $\Delta$ represent the difference, $\varepsilon_{t}$ is a white noise error term and $\Delta Y_{t-1}=Y_{t-1}$ $-Y_{t-2}$, etc. The null hypothesis is that $\delta=0$; that is there is a unit root and the

\footnotetext{
${ }^{5}$ Lag length for all variables in ADF test statistic and PP test statistic is 1.
} 
alternative hypothesis is that $\delta<0$; that means the time series is stationary. To test the null hypothesis, the calculated $t$ value is compared with the tabulated value given by Mackinnon (1991).

Moreover to OLS, the authors examine the long-run relationship among variables by cointegration test developed by Johansen (1988) and Johansen and Juselius (1990) and the short run dynamic relationship by applying the error correction techniques. For the purpose of investigating the long-run relationship among the variables, all variable must be co-integrated. For cointegration analysis we use trace and maximal likelihood statistics proposed by Johansen (1988). Further, we estimate dynamic error correction mechanism (ECM) for foreign banking activity in Pakistan obtained through using general to specific methodology for Eq. 3.

$$
\begin{aligned}
\Delta L Y_{t}= & \beta_{0}+\sum_{i=1}^{m} \beta_{1} \Delta L G_{t}+\sum_{i=1}^{m} \beta_{2} \Delta L M_{t}+\sum_{i=1}^{m} \beta_{3} \Delta L F D I_{t}+\sum_{i=1}^{m} \beta_{4} \Delta L P O P_{t} \\
& +\sum_{i=1}^{m} \beta_{5} \Delta L I N T_{t}+\sum_{i=1}^{m} \beta_{6} \Delta L R E G_{t}+\xi E C M_{t-1}+\psi E C M_{t-2}+v_{t}
\end{aligned}
$$

where $\beta i$ are the short-run dynamic coefficients and $\xi$ and $\psi$ is the long-run coefficient and $v t$ are white-noise residuals and $\mathrm{ECM}_{\mathrm{t}-1}$ and $\mathrm{ECM}_{\mathrm{t}-2}$ is error-correction mechanism term. The one and two period lagged value of the estimated error of the cointegrating regression attained from OLS estimation. The reason behind this model is that, a long-run equilibrium relationship between determinants of foreign banking activity is presented. But, in the short run it can be disequilibrium. Therefore, the ECM terms accurate a proportion of disequilibrium in the next periods. The absolute value of $\xi$ and $\psi$ determines how quickly the equilibrium is restored in preliminary and subsequent year. The sample period for study is 1973-2008 is obtained from various Economic Surveys of Pakistan, Annual Reports of SBP, and Statistical Bulletin of SBP for the analysis software E-Views version 5.0 is used.

\section{Empirical Results}

The results of the ADF unit root test (1979) and Phillips-Perron test (1988) are reported in Table 1 with trend and without trend. The results reveal that all variables are non-stationary on level. However, stationarity is found at the first difference level of the variables.

The estimated outcomes of OLS are shown in Table 2. The outcomes reveals that the GDP growth rate is statistically insignificant, with the negative sign, which shows that foreign banks could not take benefits from the growth of Pakistan due to Pakistan society is consumption oriented society towards luxuries items. The variable FDI effect positively significant on growth of foreign banks deposits, which illustrate that in Pakistan FDI comes in services sector due to high rate of return and investment friendly policies and with the rising of FDI the deposits of foreign banks rises. Higher FDI flows could imply more openness, and thereby a higher rate of convergence or access to advanced technology has enhanced the foreign banks in 
Table 1 Results of unit roots

\begin{tabular}{|c|c|c|c|c|}
\hline \multirow[t]{2}{*}{ Variables } & \multicolumn{2}{|c|}{ ADF test statistic } & \multicolumn{2}{|c|}{ PP test statistics } \\
\hline & With trend & Without trend & With trend & Without trend \\
\hline $\mathrm{Y}$ & -2.417052 & -0.418712 & -2.248266 & -0.304630 \\
\hline$\Delta \mathrm{Y}$ & -4.412957 & -4.435501 & -4.977097 & -5.015081 \\
\hline G & -3.230789 & -3.317503 & -4.359790 & -4.349899 \\
\hline$\Delta \mathrm{G}$ & -5.649524 & -5.783101 & -8.683009 & -8.766186 \\
\hline FDI & -4.255176 & -2.059027 & -3.202240 & -1.770330 \\
\hline$\Delta \mathrm{FDI}$ & -5.777870 & -5.774349 & -4.305745 & -4.527542 \\
\hline POP & -2.886185 & 0.627859 & -2.886373 & 0.758778 \\
\hline$\Delta \mathrm{POP}$ & -4.203153 & -4.188952 & -5.767265 & -5.757643 \\
\hline INT & -2.367171 & -2.481526 & -2.212739 & -2.347641 \\
\hline$\Delta \mathrm{NT}$ & -3.542362 & -3.554753 & -5.207911 & -5.230027 \\
\hline REG. & -3.314686 & -2.906768 & -5.419979 & -5.112217 \\
\hline$\triangle \mathrm{REG}$ & -5.505270 & -5.579386 & -10.88915 & -11.05976 \\
\hline M & -1.660313 & -1.724248 & -2.143141 & -2.222726 \\
\hline$\Delta \mathrm{M}$ & -4.762310 & -4.637641 & -6.125778 & -6.090822 \\
\hline
\end{tabular}

Source Author's estimation

Table 2 OLS estimated result

\begin{tabular}{lllll}
\hline Variable & Coefficient & SE & $T$ statistic & Prob. \\
\hline C & -0.428 & 0.275 & -1.552 & 0.131 \\
LG & -0.010 & 0.011 & -0.939 & 0.355 \\
LM & 0.039 & 0.006 & 6.588 & 0.000 \\
LFDI & 0.180 & 0.045 & 3.948 & 0.000 \\
LPOP & 0.030 & 0.001 & 21.985 & 0.000 \\
LINT & 0.039 & 0.009 & 3.966 & 0.000 \\
REG. & 0.120 & 0.043 & 2.773 & 0.009 \\
$R^{2}=0.98$ & $F$ statistic 254.592(0.000) & DW stat. 1.72 & \\
\hline
\end{tabular}

Source Authors estimation

Pakistan. The positive coefficient of interest rate represents that high rate of return in host countries always boost the activity of foreign banks in host country and further raise the deposits of foreign bank. In Pakistan the foreign banks can take benefits of higher profitability. The positive sign of the coefficient of Population (market size) indicated larger domestic market, which offer the potential for exploiting economies of scale and declining the marginal costs of production, enhances the foreign banking activity in banking industry of Pakistan and offer the large foreign markets to expanding their activities.

The coefficient of regulation factor demonstrate the positive and significant relationship with the increasing of foreign banks deposits in Pakistan means 
favorable Govt. policies of host country related to foreign banks entry will significantly impact on the deposits of foreign banks.

The sign of trade to GDP ratio have showed positive and significant relationship with deposits of foreign banks as the presence of foreign banks provided financial support to trade through their relationship with the international financial markets and facilitated the entry of foreign capital. The trade financing activities influences both the entry decision and the activity level of foreign banks.

The results of cointegration analysis shows in Table 3. We used lag length 2 by using Schwartz Bayesian criteria (SBC), the results of Max-Eigen value and trace statistics obtained by using the assumption of linear deterministic trend in the data are presented. Trace test indicates those four co-integrating equations at the $5 \%$ level whilst the Max-Eigen value test indicates three co-integrating equations at the $5 \%$. Therefore, our analysis indicated the existence of long run relationship among variables and strongly supports the hypothesis that market size, trade financing, FDI and corporate financing are the major determinants of foreign banks in Pakistan. The higher profitability and smooth Govt. policies always enhance the activity of foreign banks in Pakistan in various decades.

Table 4 presents the long run equation, ${ }^{6}$ which is derived by normalizing on foreign banks deposits based on estimated co integration coefficient. All the coefficients are positive as per theoretical expectation, which signified that trade, GDP population, interest rate and regulatory factor effects positively significantly on the growth of foreign banks deposits in the long run.

Table 3 Johansen co-integration test results

\begin{tabular}{llclll}
\hline Null & Alternate & $\lambda_{\max }^{\text {a }}$ statistics & Critical value 5\% & Trace statistics & Critical value 5\% \\
\hline$r=0$ & $r=1$ & $114.6518^{*}$ & 50.59985 & $302.9957^{*}$ & 150.5585 \\
$r \leq 1$ & $r=2$ & $67.75867^{*}$ & 44.49720 & $188.3439^{*}$ & 117.7082 \\
$r \leq 2$ & $r=3$ & $51.07501^{*}$ & 38.33101 & $120.5853^{*}$ & 88.80380 \\
$r \leq 3$ & $r=4$ & 31.31505 & 32.11832 & $69.51025^{*}$ & 63.87610 \\
$r \leq 4$ & $r=5$ & 18.82019 & 25.82321 & 38.19520 & 42.91525 \\
$r \leq 5$ & $r=6$ & 11.69103 & 19.38704 & 19.37501 & 25.87211 \\
$r \leq 6$ & $r=7$ & 7.683979 & 12.51798 & 0.2786 & 12.51798 \\
\hline
\end{tabular}

Lag interval on first difference is 2

Max-Eigen statistics

Table 4 Estimated co-integration derived by normalizing on foreign banks deposits

\begin{tabular}{lllllllc}
\hline & Constant & LG & LM & LFDI & LPOP & LINT & REG. \\
\hline Coefficients & -0.033 & 0.031 & 0.067 & 0.021 & 0.016 & 0.029 & 0.289 \\
$T$ statistics & -4.706 & $8.137^{*}$ & $37.559^{*}$ & 1.292 & $6.268^{*}$ & $12.519^{*}$ & $27.468^{*}$ \\
\hline
\end{tabular}

Source Author's estimation

* Significant at $1 \%$

\footnotetext{
${ }^{6}$ Lag length for long run model is based on SIC criteria base.
} 
Table 5 Short run error correction model of foreign banking activity in Pakistan

\begin{tabular}{lcc}
\hline Explanatory variables & Coefficient & $T$ statistics \\
\hline C & 0.102 & 3.052 \\
LG & 0.234 & 5.68 \\
LM & 0.016 & 2.33 \\
LFDI & 0.294 & 0.53 \\
LPOP & 0.532 & 8.29 \\
LINT & 1.013 & 6.24 \\
REG. & 0.386 & 1.68 \\
ECM $(-1)$ & -0.288 & -2.61 \\
ECM $(-2)$ & -0.374 & -3.07 \\
\hline
\end{tabular}

Table 5 reports the results of the ECM. According to Engle and Granger (1987), co-integrated variables must integrate the ECM. More specifically, the ECM measures the speed of adjustment back to co-integrated relationships. The ECM identifies the forces returning the integrated variables to their long-run equilibrium of $100 \%$ their capital, when they deviate from it and thus the longer the deviation, the greater the force to correct the deviation.

The value of ECM $(-1)$ and ECM $(-2)$ is statistically significant suggesting powerful long run corrections in initial and subsequent year. ECM (-1) indicates that approximately $28 \%$ of the disequilibrium is corrected immediately and $37 \%$ will be corrected in the subsequent year. Our results strongly supports the hypothesis that the purpose of opening of new branches of foreign banks is mainly financed the trade and corporate activities in host country with high rate of return and $100 \%$ return back of their capital. The main aim of liberalization of banking sector is to improve efficiency, competition, risk diversification and to bring new technology for banking sector.

\section{Conclusion and Policy Implication}

Many foreign banks have aggravated to enter due to rising integration of developing countries like Pakistan in terms of trade and corporate with the combination of substantial growth, financial sector liberalization a market size, trade and corporate financing and technology advances. In developing nations, the majority of foreign banks existence is from high income countries due to the high rate of return and higher efficiency and technology. This paper examines the factors which determine the foreign banks activity in Pakistan for the period 1973-2008 in the context of central bank's policy framework. High efficiency and an effective banking regulation from foreign countries seem to have positive effects on the activity of foreign banks in Pakistan since 1990s financial sector in Pakistan was liberalized with the objective to improve performance and competition in the service sector.

The outcomes indicated that foreign banks with trade and corporate financing as their main activity is benefited with the growth of Pakistan economy in the long run and short run period and also impact on the market concentration of banking 
industry. Low profitability and high cost of doing business in the home country was one of the mostly cited push factors that led foreign banks to pursue opportunities in the Pakistani financial market with high profit potential.

Pakistan may acquire benefits with the growth of foreign banking activity by improving their efficiency, competitiveness and trade financing activities in the long run and short run period. The increase in foreign banking activity in Pakistan can improve the services of domestic sector also with the introduction of new services, improving monitoring, decreasing of non-performing loans and gain from technology know-how brought by parental foreign banks. The foreign banks can increases the profitability of domestic banks due to gained of operating efficiency.

Pakistan can take benefits from foreign banks as foreign banks in Pakistan can promote stability and efficiency by reforming and streamlining the financial system and removing of barriers to foreign banks investments like uncertainty, information asymmetry and other unseen costs.

\section{Appendix}

See Tables 6 and 7.

Table 6 Historical development of foreign banks in Pakistan

\begin{tabular}{lllcc}
\hline Years & $\begin{array}{l}\text { No. of foreign } \\
\text { banks }\end{array}$ & $\begin{array}{l}\text { No. of } \\
\text { branches }\end{array}$ & $\begin{array}{l}\text { Deposits of foreign } \\
\text { banks (Rs. million) }\end{array}$ & $\begin{array}{l}\text { Growth of foreign } \\
\text { bank deposits } \%\end{array}$ \\
\hline 1975 & 17 & 36 & $2,037.9$ & 8.97 \\
1980 & 21 & 56 & $5,379.4$ & 28.42 \\
1985 & 25 & 61 & $13,750.2$ & 15.08 \\
1990 & 26 & 67 & $42,348.0$ & 22.04 \\
1995 & 22 & 74 & $127,364.0$ & 5.82 \\
2000 & 19 & 85 & $153,431.7$ & 14.4 \\
2005 & 11 & 81 & $188,549.3$ & 3.86 \\
2008 & 07 & 64 & $209,619.8$ & 3.50 \\
\hline
\end{tabular}

Source: SBP (Various issues) Annual Report, State Bank of Pakistan

Table 7 Foreign banks in Pakistan

\begin{tabular}{lcll}
\hline Name of foreign banks & No. of branches & Year of registration & Location of head offices \\
\hline Abn-Amro N.R & 13 & 1948 & Holland \\
Al-Baraka (Islamic bank) & 11 & 1991 & Bahrain \\
Citi Bank & 21 & 1961 & USA \\
Deutsche Bank A.G & 2 & 1962 & Germany \\
Oman International Bank & 2 & 1979 & Oman \\
Bank of Tokyo Mitsubishi & 1 & 1996 & Japan \\
\hline
\end{tabular}


Table 7 continued

\begin{tabular}{lcll}
\hline Name of foreign banks & No. of branches & Year of registration & Location of head offices \\
\hline Hong Kong and Shanghai Bank & 5 & 1982 & Hong Kong \\
Standard Chartered Bank & 116 & 1947 & UK \\
Habib Bank A.G Zurich & 17 & 1967 & Switzerland \\
American Express Bank & 4 & 1972 & USA \\
\hline
\end{tabular}

Source Banks reports

\section{References}

Ahmad KM, Rosly SAB (1995) Determinants of foreign banking activity in Malaysia. Int J Dev Bank 13(1):25-34

Akmal M, Saleem M (2008) Technical efficiency of the banking sector in Pakistan. SBP Res Bull 4(1):61-80

Claessens S, Lee JK (2002) Foreign banks in low-income countries: recent developments and impacts. http://www1.fee.uva.nl/fm/PAPERS/Claessens/foreign\%20banks.pdf

Clarke G, Cull R, Peria MSM, Sanchez SM (2001) Foreign bank entry: experience, implications for developing countries, and agenda for further research. The World Bank Policy Research Working Paper Series, with number 2698

Detragiache E, Gupta P, Tressel T (2006) Foreign banks in poor countries: theory and evidence. Paper presented at the 7th Jacques Polak Annual Research Conference, Washington, DC, November 2006

Dickey DA, Fuller WA (1979) Distribution of the estimation for autoregressive time series with a unit root. J Am Stat Assoc 79:355-367

Engle RF, Granger GWJ (1987) Co-integration and error correction: representation. Estim Test Econom 55:251-276

Fisher A, Molyneux P (1996) A note on the determinants of foreign bank activity in London between 1980 and 1989. J Appl Financ Econ 6:271-277

Haddad M, Hakim S (2009) Have foreign banks contributed to the spread of the global financial crisis to Saudi Arabia? In: Shocks, vulnerability and therapy, ERF 16th annual conference, Egypt, November

Haselmann R (2006) Strategies of foreign banks in transition economies. J Emerg Markets Rev 7(4):283-299

Horen NV (2006) Foreign banking in developing countries. Orig Matters Emerg Markets Rev 8(2):81-105

Johansen S (1988) Statistical analysis of cointegrating vectors. J Econ Dyn Control 12:231-254

Johansen S, Juselius K (1990) Maximum likelihood estimation and inference on cointegration with applications to the demand for money. Oxf Bull Econ Stat 52(2):169-210

Lehner M, Schnitzer M (2006) Entry of foreign banks and their impact on host countries centre for economic policy research (CEPR). CEPR Discussion Paper No. 595

Lensink R, Hermes N (2004) The short-term effects of foreign bank entry on domestic bank behaviour: Does economic development matter? J Bank Finance 28:553-568

MACKINNON JG (1991) Critical Values for Cointegration Tests. In: Engle RF, Granger CWJ (eds) Long-run Economic Relationships Oxford University Press, Oxford

Palit A, Nawani S (2007) Technological capability as determinant of FDI inflows: evidence from developing Asia and India. Indian Council of Research on International Economic Relations (ICRIER), working paper No. 193

Paula LFRD (2003) The determinants of the recent entry of foreign banks in Brazil. Associação Brasileira de Pesquisadores em História Econômica (Brazilian Economic History Society) Series number 023

Phillips PCB, Perron P (1988) Testing for a unit root in time series regressions. Biometrika 75:335-346

Sathye M (2002) The impact of foreign banks on market concentration: the case of India. Appl Econom Int Dev (AEEADE) 2(1):7-20

Sonin C, Yudkevich M (2000) Impact of foreign bank admission at domestic banking sectors in transitional economies on financial institutions and enterprise restructuring. http://www.umar.gov.si/ fileadmin/user_upload/konference/07/16_yudkevic.pdf 
Wezel T (2004) Foreign bank entry into emerging economies: an empirical assessment of the determinants and risks predicated on German FDI data. Deutsche Bundesbank Discussion Paper Series 1: Studies of the Economic Research Centre No. 01/2004

World Bank (2001) Finance for Growth: Policy Choices in a Volatile World. World Bank, Washington, DC 